\title{
The Fungicidal action of Some Natural Products \\ (Denture cleansers ) on Acrylic Denture Base Material
}

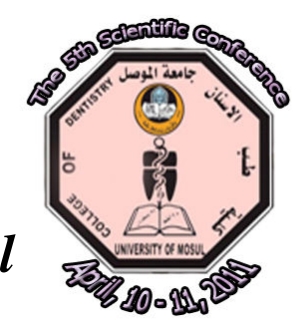

\section{Abstract:}

Aim: To evaluate some natural products (soda+ vinegar, soda + thymol, saturated salt solution) compared with the commercial denture cleanser (Protifex), for disinfection of acrylic denture base material from C. albicans (in vitro ). Materials And Methods: Thirty five samples, (10 × $10 \times 2 \mathrm{~mm}$ length, width, and thickness respectively), were prepared from heat cured acrylic resin denture base material (Major heat cured acrylic resin ), using MacFarland Standard Bacteriologica Solution technique, tube No.2., using a light microscope with camera connected to computer for testing anti fungal efficiency of these natural denture cleansers (soda, vinegar, thymol, saturated salt solution). This procedure was done after 1hour, 4hours, and 8 hours of immersion. in comparison with samples immersed in distilled water, (Control). Results: The results demonstrated that at $\mathrm{P}=0.05$ there were significant differences between all prepared solutions and control. The best prepared natural solution was saturated salt solution. There were significant differences between all times of immersion, the best was 8hrs. Conclusions: All the prepared natural denture cleansers were considered as fungicidal disinfectants, and a proper disinfection of the acrylic denture base material requires $8 \mathrm{hrs}$ of immersion in the prepared disinfectant solutions. The best prepared natural solution was saturated salt solution.

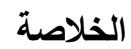

الهُف : تهدف هذه الدراسة لتقييم بعض المنتجات الطبيعية (صودا الخل + الصودا

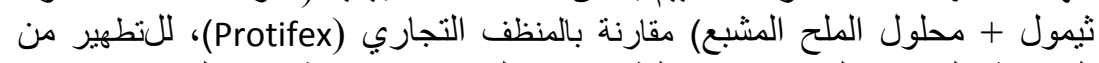

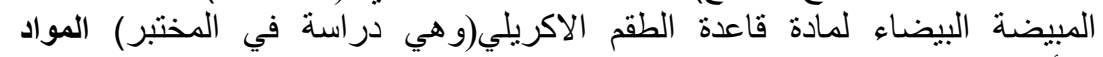

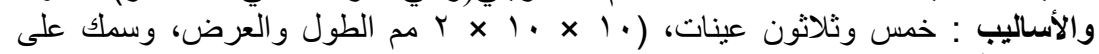

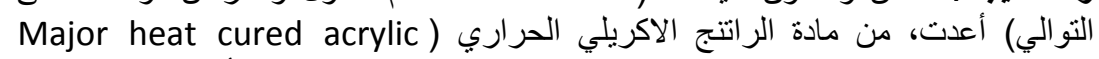
resin

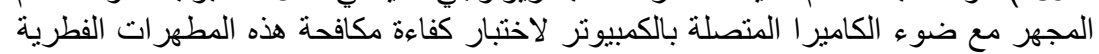

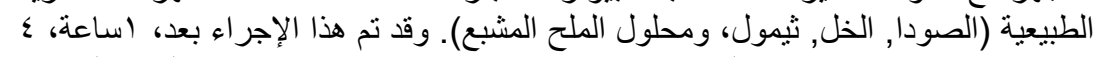

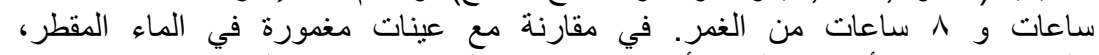

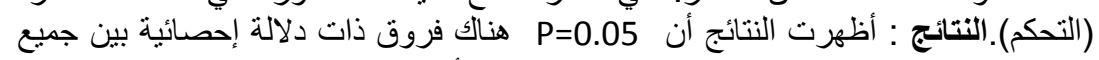

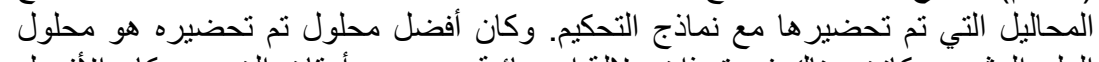

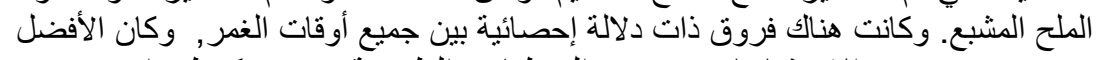

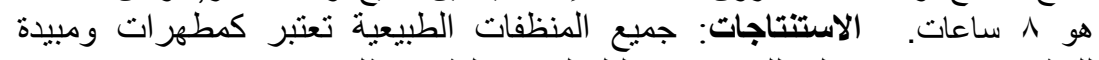

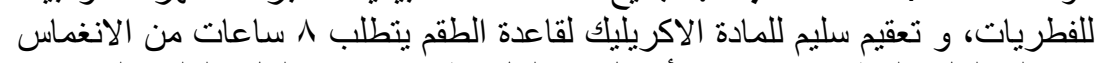

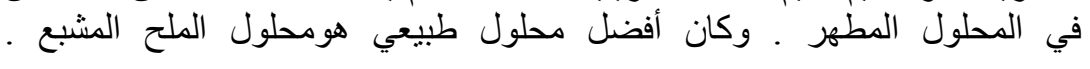

Prof Nadira A. Hatim (BDS, MSC); Asst Lect Rana Rabee AL- Sumaidaẻ $(B D S, M S c)$
Department of Prosthodontics, Dentistry College, Mosul University

Key words: Denture cleanser, anti fungal, acrylic resin. 
he word "disinfection" signifies the elimination of hazards of infection, i.e. the removal or destruction of the infective agent, with the exception of bacterial spores ${ }^{(1-3)}$.

Acrylic resin is the most employed material in the construction of removable complete denture ${ }^{(4-5)}$.Chemical cleansing approach is recommended for plaque control ${ }^{(6-10)}$ as an alternative to the mechanical approach in patients with lack of motor coordination ${ }^{(11)}$. Every surface in the oral cavity, natural, or synthetic, becomes covered within 30 minutes with $0.5-1.5$ $\mu$ thickness precipitate of salivary glycoprotein, and immunoglobulin, that is termed "pellicle"(11). The pellicle in turn provides a substrate to which oral debris; (mucin, food particles, desquamated epithelial cells, and microorganisms "bacteria, and fungi" readily adhere ${ }^{(12)}$.

Many studies had shown that Candida species, and other microorganisms, including species of Streptococcus, Staphylococcus, Lactobacillus bacteria, and Actinomyces are associated with denture plaque ${ }^{(13)}$. The worldwide overuse of antibiotics has caused microorganisms to develop resistance to the current antibiotics, and to become virulent, therefore, antibiotic resistance is a global problem, and dentists must be involved in halting it $^{(14)}$.

The purpose of this study was to evaluate the effect of the natural denture cleansers disinfection of $C$. albicans for acrylic denture base material.

\section{MATERIALS AND METHODS}

Thirty five specimen of acrylic denture base material used for testing antifungal efficiency of used denture cleansers (In vitro study) on C. albicans. Specimens are of $(10 \times 10 \times 2 \mathrm{~mm}$ length, width and thickness respectively) according to Webb et al. ${ }^{(1)}$, Flasking was done by mixing in ratio of $28-32 \mathrm{ml}$ of water: $100 \mathrm{gm}$ of stone, the procedure was done in the conventional method $^{(1)}$. Packing and Curing were carried out by placing the clamped flask in the thermostatically controlled water bath for $\left(1 \mathrm{hr}\right.$ at $74^{\circ} \mathrm{C}$ then $1 / 2 \mathrm{hr}$ at $\left.100^{\circ} \mathrm{C}\right)$, according to the manufacturer instructions. After the completion of curing, flasks were allowed to bench cool for 30minuts. The acrylic specimens were removed from their stone moulds.

By using MacFarland Standard Bacteriological Solution technique, tube No.2., and using light microscope with camera, connected to computer (Figure 1). The culture media, and acrylic specimens were sterilized by using an autoclave at 15 pound $/ \mathrm{inch}^{2}$ at $121^{\circ} \mathrm{C}$ for $15 \mathrm{~min}$., while glass Petri-dishes, screw cap bottles, and tweezers were sterilized by hot air oven at $(160-180)^{\circ} \mathrm{C}$ for 1 hour ${ }^{(15)}$. This procedure was done after 1hour, 4hours, and 8 hours of immersion in the five prepared solutions. They were prepared by Khalil ${ }^{(16)}$, and one commercial denture cleanser tablets (Protifex) for comparison, and distilled water as a control solution .Every solution was diluted in $100 \mathrm{ml}$ of distilled water (Table 1)

For the identification of $\mathrm{C}$. albicans the diagnostic laboratory tests used include: Culture characteristics: On Sabouraud's Dextrose Agar medium within (24-48)hrs at $37{ }^{\circ} \mathrm{C}$, Candida species produce soft creamy-coloured colonies with a yeast odor ${ }^{(14,17)}$ Figure (2).

Microscopic Examination: The smears that had been obtained from the patients were examined by light microscopic using a gram's stain technique for pseudohyphae and budding ${ }^{(14,17)}$ Figure ( 3), and Germs Tube Test: In this test, a loopfull was taken from each culture, incubated in test tubes containing human serum $(0.5-1) \mathrm{ml}$ for about $90 \mathrm{~min}$ intervals at $37^{\circ} \mathrm{C}$ $(17,18)$. Microscopic observation made for a smear obtained from each test tube. The yeast cells of C. albicans will begin to form germ tubes or true hyphae after $30 \mathrm{~min}^{(19)}$.

Journal of the $5^{\text {th }}$ Scientific Conference of Dentistry College, Apr. 2011 
The procedure involved preparing the MacFarland Standard Bacteriological Solution (tube No. $2=600 * 10^{\wedge} 6 \mathrm{CFU} / \mathrm{ml}$ ) that composed of $0.2 \mathrm{ml}$. Barium Chloride of $1 \%$, and $9.8 \mathrm{ml}$. $\mathrm{H} 2 \mathrm{SO} 4$ of $1 \%{ }^{(20)}$. (prepare new culture of pure C. albicans (so it will be fresh and in the active face), mix loop full $C$. albicans for several times with sterile distilled water to prepare a bacterial suspension matching MacFarland Standard Bacteriological Solution tube No.2. by using U.V. spectrophotometer (CECIL), then $1 \mathrm{ml}$. of the prepared bacterial suspension was put in five screw capped bottles, then, one sterile wax specimen was immersed in each one, then incubated for $24 \mathrm{hrs}$ at $37^{\circ} \mathrm{C}$, where after incubation $0.01 \mathrm{ml}$. of the bacterial suspension was taken, and plated on Sabouroid agar for counting of $C$. albicans colonies after incubation for $24 \mathrm{hrs}$ at $37^{\circ} \mathrm{C}$. (to check the count of viable species only).After that, each wax specimen was removed from their screw capped bottles by using sterile tweezers, then each one was placed in a screw capped bottle containing $(1 \mathrm{ml})$ of one of the five prepared solutions. then $0.01 \mathrm{ml}$ of solutions was taken from each screw capped bottle, and plated on sabouroid agar for counting of colonies as ( $\mathrm{CFU} / \mathrm{ml})$ after the C. albicans was incubated for $\left(24 \mathrm{hrs}\right.$ at $\left.37^{\circ} \mathrm{C}\right)$. This procedure was done after 1hour, 4hours, and 8 hours of immersion in the five prepared solutions.

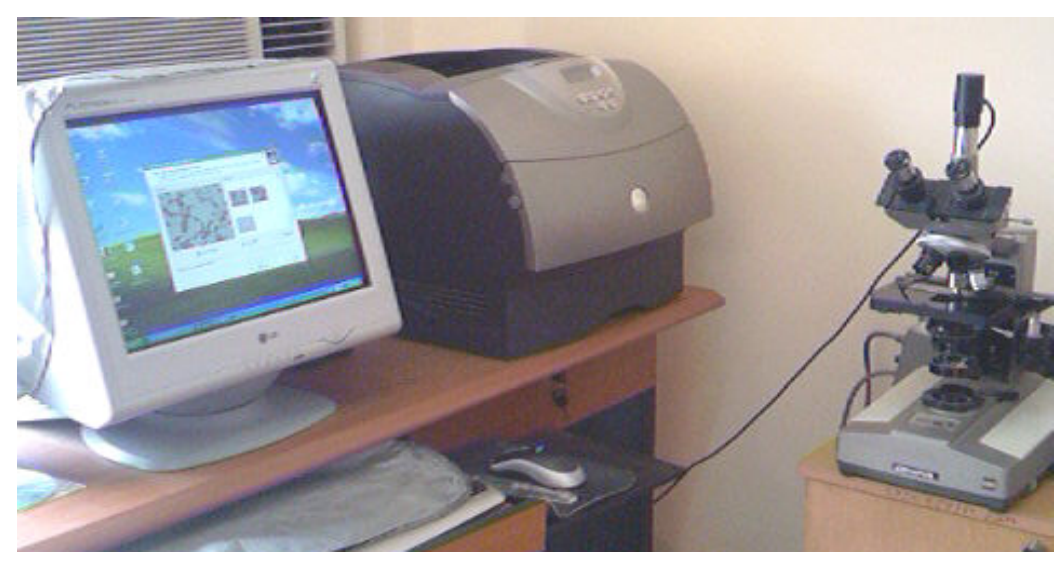

(Figure 1) Light microscope with camera connected to computer

Table (1) Solutions Preparation

\begin{tabular}{ccccc}
$\begin{array}{c}\text { Solution } \\
\text { no. }\end{array}$ & Material 1 & $\begin{array}{c}\text { Weight or } \\
\text { volume }\end{array}$ & Material 2 & $\begin{array}{c}\text { Weight or } \\
\text { volume }\end{array}$ \\
$\mathbf{1}$ & Soda & $7 \mathrm{~g}$ & Clear vinegar & $5 \mathrm{ml}$ \\
$\mathbf{2}$ & Soda & $2 \mathrm{~g}$ & Thyme oil & $3.57 \mathrm{~g}$ \\
$\mathbf{3}$ & Saturated salt & $40 \mathrm{~g}$ & & \\
$\mathbf{4}$ & Distilled water & $100 \mathrm{ml}$ & & \\
$\mathbf{5}$ & Protefix & $1 \mathrm{tab}=2.85$ & & \\
\hline
\end{tabular}




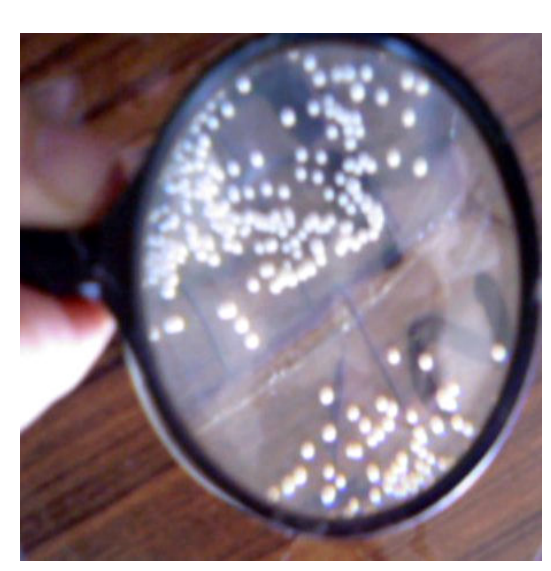

(Figure 2) C. albicans on SDA

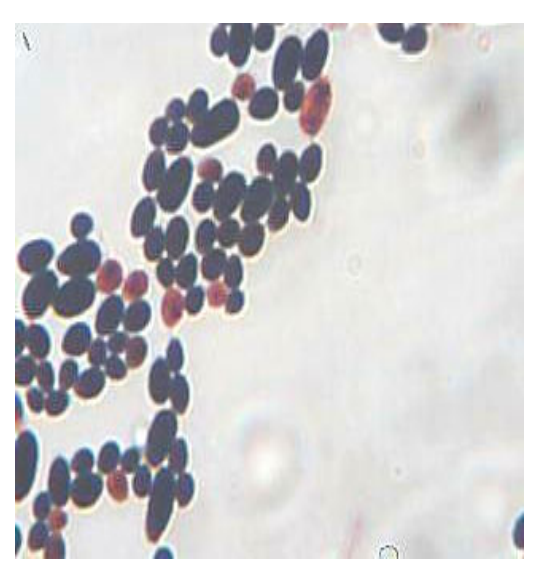

(Figure 3) C.albicans, microscopically

\section{RESULLTS}

The mean, standard error, and number of samples and 95\% Confidence Interval for antifungal action on acrylic denture base are shown in (Table 2, and Figure 4), Duncan's multiple range test (Table 3) showed that at $\mathrm{P}=0.05$, there were significant differences between all prepared solutions, and control. The best prepared natural solution was saturated salt solution. Duncan's multiple rang test (Table 4) showed that at $\mathrm{P}=0.05$, there were significant differences between all times, the best was $8 \mathrm{hrs}$.

Table (2) :Descriptive statistics for disinfection of acrylic denture base from C. albicans.

\begin{tabular}{|c|c|c|c|c|c|}
\hline \multirow{2}{*}{ TREATS } & \multirow{2}{*}{ Time of immersion } & \multirow{2}{*}{$\begin{array}{c}\text { Mean } \\
\text { ( CFU/ml) }\end{array}$} & \multirow{2}{*}{ S. E } & \multicolumn{2}{|c|}{ 95\% Confidence Interval } \\
\hline & & & & Lower Bound & Upper Bound \\
\hline \multirow[t]{3}{*}{ D.W } & 1 Hour & 357500.000 & 3751.755 & 349503.323 & 365496.677 \\
\hline & 4 Hours & 404000.000 & 3751.755 & 396003.323 & 411996.677 \\
\hline & 8 Hours & 499000.000 & 3751.755 & 491003.323 & 506996.677 \\
\hline \multirow[t]{3}{*}{ Salt } & 1 Hour & 112000.000 & 3751.755 & 104003.323 & 119996.677 \\
\hline & 4 Hours & 57500.000 & 3751.755 & 49503.323 & 65496.677 \\
\hline & 8 Hours & 7000.000 & 3751.755 & -996.677 & 14996.677 \\
\hline \multirow{3}{*}{ Protefix } & 1 Hour & 4750.000 & 3751.755 & -3246.677 & 12746.677 \\
\hline & 4 Hours & 2250.000 & 3751.755 & -5746.677 & 10246.677 \\
\hline & 8 Hours & 100.000 & 3751.755 & -7896.677 & 8096.677 \\
\hline \multirow[t]{3}{*}{ S.+ving } & 1 Hour & 307000.000 & 3751.755 & 299003.323 & 314996.677 \\
\hline & 4 Hours & 246000 & 3751.755 & 238003.323 & 253996.677 \\
\hline & 8 Hours & 95000.000 & 3751.755 & 87003.323 & 102996.677 \\
\hline \multirow[t]{3}{*}{ S.+Thy } & 1 Hour & 327500.000 & 3751.755 & 319503.323 & 335496.677 \\
\hline & 4 Hours & 287500.000 & 3751.755 & 279503.323 & 295496.677 \\
\hline & 8 Hours & 257000.000 & 3751.755 & 249003.323 & 264996.677 \\
\hline
\end{tabular}

S.E: standard error 


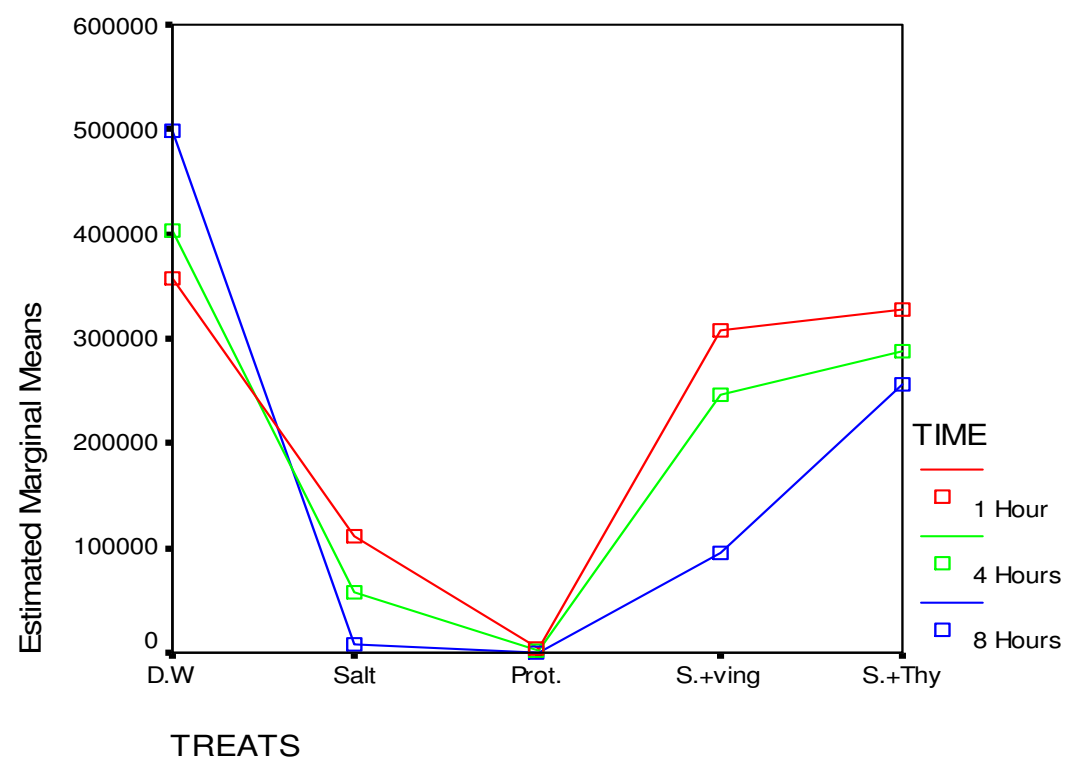

Figure (4) The mean for the disinfection of Acrylic denture base from C. albicans.

Table (3) Duncan multiple range test for disinfection of acrylic denture base material from $C$.

\begin{tabular}{cccccccc} 
& & \multicolumn{7}{c}{ albicans, between treats: } \\
TREATS & $\mathbf{N}$ & $\mathbf{1}$ & $\mathbf{2}$ & $\mathbf{3}$ & $\mathbf{4}$ & $\mathbf{5}$ \\
Duncan & Protefix & 6 & 2366.6667 & & & & \\
Salt & 6 & & 58833.3333 & & & \\
S.+ving & 6 & & & 216000.0000 & & \\
S.+Thy & 6 & & & & 290666.6667 & \\
D.W & 6 & & & & & 420166.6667 \\
\hline Sig. & 1.000 & 1.000 & 1.000 & 1.000 & 1.000 \\
\hline N: number of samples & & & & &
\end{tabular}

Table (4) Duncan multiple range test for disinfection of acrylic denture base material from $C$.

\begin{tabular}{cccccc}
\multicolumn{5}{c}{} & \multicolumn{5}{c}{ albicans, between times: } & Subset & \\
\multirow{5}{*}{ Duncan } & TIME & $\mathbf{N}$ & $\mathbf{1}$ & $\mathbf{2}$ & $\mathbf{3}$ \\
& 8 Hours & 10 & 171620.0000 & & \\
& 4 Hours & 10 & & 199450.0000 & \\
1 Hour & 10 & & & 221750.0000 \\
Sig. & & 1.000 & 1.000 & 1.000 \\
\hline
\end{tabular}

$\mathrm{N}$ : number of samples

\section{DISCUSSION}

The results showed that there were significant differences between all treats, and the control. So, all prepared natural denture cleansers are effective in disinfection of acrylic denture 
base material from $C$. albicans. The best prepared natural solution was saturated salt solution, and this agrees with Baltch et al. ${ }^{(21)}$ where he stated that salt had antibacterial action against $(C$. albicans, S. aureus, Pseudomonas aeruginosa, and Legionella pneumophila) and that C. albicans was the most sensitive organism to salt. The best time of immersion was 8hours, this was in disagreement with Queisser Pharma ${ }^{(22)}$ which stated that her product (Protefix) insured complete cleaning, and disinfection within 15 minutes only, and disagreed with Pavarina et al. ${ }^{(23)}$ who concluded that immersion of denture in one of three solutions, $3.78 \%$ alkaline peroxide, $4 \%$ chlorhixidine gluconate, $1 \%$ sodium hypochlorite for about 10 minutes was effective in reducing microbial growth.

\section{CONCLUSIONS}

All the prepared natural denture cleansers were accepted, and considered as fungicidal disinfectant, and a proper disinfection of the acrylic denture base material requires $8 \mathrm{hrs}$ of immersion in the prepared disinfectant solutions.

\section{REFERENCES}

1. Webb BC, Thomas CJ, Harty DWS and Willcox MDP. Effectiveness of two methods of denture sterilization. $J$ of Oral Rehabil. 1998; 25:416-423.

2. Elkin II: A coarse in epidemiology. Pergman Press Ltd.1961; (13):135-162.

3. Gardner JF, Peel MM, and Kelsey JC. Introduction to sterilization and disinfection. $1^{\text {st }}$.ed., Churchill Livingstone Longman Group Limited.1986, Pp.10,11,131 and 150.

4. Anusavice KJ. Philips science of dental material. 10 ${ }^{\text {th }}$ ed., W.B.Saunders Co. 1996; Pp: 211-271.

5. Gunningham JL (2000). Shear bond strength of resin teeth to heat cured and light cured denture base resin. J Oral Rehabil ; 27:312-316.

6. Pipko JD, El-Sadeek M. An in vitro investigation of abrasion and staining of dental resin. J Dent Res.1972; 15: 689693.

7. Dills SS, Olsen AM, Goldner S. Comparison of antimicrobial capability of an abrasive paste and chemical soak denture cleansers. J Prosthet Dent.1988; 60:467.

8. McCabe JF, Davidmurry J, Kelly PJ. The efficacy of denture cleansers. Eur J Prosthdont Res Dent.1995; 3(4): 203207.

9. Nikawa H, Yamamoto T, Hamada T, Sadomori S. Cleansing efficacy of commercial denture cleansers: ability to reduce Candida albicans biofilm activity. Int J Prosthet. 1995; 8 :527-534.

10. Haselden CA, Hoblirk JA, Pearson GJ, Davis EH. A comparison between the wear resistance of three types of denture resin to three different dentifrices. J Oral Rehabil.1998; 25:335-339.

11. Odman PA. The effectiveness of enzyme containing denture cleanser . Quintessence Int J.1992; $23: 187$.

12. Craig RG, O' brien WJ, Powers JM. Dental materials, properties and manipulation. $6^{\text {th }}$ ed. Mosby Co.1996. Pp. $97-$ $133,242-265$.

13. Budtz-Jorgensen E, Thielade E. Quantitative relationship between yeast and bacteria in denture induced stomatitis . Scand Dent Res. $1982 ; 91: 142-143$.

14. Jawetz E, Melnick JK, Adelbrg EA. Medical microbiology. Lange medical book. $21^{\text {st }}$ ed. Appleton and Lange, Norwalk, Connecticut/San Mateo, California.USA.1998,Pp.603-605, 611-14.

15. Baker FJ, Silverton RE. Introduction to medical laboratory technology. $5^{\text {th }}$ ed. Butter worth's Publication, London.1985. Pp.350-354,465-475.

16. Khalil SM. New Denture Cleansers. Thesis; College of Dentistry-Mosul; 2006.

17. Koneman EW, Allen SD, Janda WM, Schreckenberger PC,Winn WC. Color Atlas and textbook of diagnostic microbiology. $5^{\text {th }}$ ed.1997. Pp 539-615.

18. Forbes BA, Sahm DF, Weissfeld AS. Bailey and Scotts: Diagnostic Microbiology. $10^{\text {th }}$ ed. Mosby, Inc. USA.1998.Pp. 941-960.

19. Barlow AJ, Aldersly t, Challaway FW. Factors present in serum and plasma which promote germ tube formation and mycelial growth of Candida albicans. J Gen microbial . 1974; 82: 261-272.

20. Kazazoglu E, Kulak Y, Kadir T. An effect of mouth spray on denture microorganisms; An in vitro and in vivo studies. Gerodontology; Marmara. Turkey.2003; 1: 1-15. 
21. Baltch AL, Smith R P, Franke M A, Ritz W J , Michelsen P, Bopp LH , Singh J K. Microbicidal activity of MDI-P against Candida albicans, Staphylococcus aureus, Pseudomonas aeruginosa, and Legionella pneumophila.$A m \quad J$ Infec .2007; 28: (3): 251-257

22. Queisser Pharma.com (2008) . Protefix- Active cleanser.

23. Pavarina AC, Machada AL, Giampaldo ET and Vergani CE. Effect of chemical disinfection on transverse strength of denture base acrylic resin. J Oral Rehabil.2003; 30: 1085 - 1089. 